\title{
An Empirical Analysis of Social Dimension Factors Towards Better IT Service Quality for Malaysian Public Agencies
}

\author{
Norhafizah Hanzah $^{1 *}$, Hidayah Sulaiman ${ }^{2}$ \\ ${ }^{1}$ College of Graduate Studies, Universiti Tenaga Nasional, \\ Putrajaya Campus, Selangor, Malaysia \\ ${ }^{2}$ Information Systems Department, Universiti Tenaga Nasional, \\ Putrajaya Campus, Selangor, Malaysia \\ *Corresponding author E-mail: afezahanzah@gmail.com
}

\begin{abstract}
Information technology (IT) has become an important part in enabling business decisions and strategies in organizations. The IT unit established in various organizations is responsible to ensure that different business units receive the expected level of technical assistance which they require. However, in many cases, the common understanding between business and IT is rarely achieved. This leads to the debate on how business and IT can be aligned in ensuring better IT services is provided to the end-users. Hence, there is a need to identify critical social factors that lead to better alignment thus leads to better service quality. This paper aims to concept ualize how businessIT alignment would have the impact to IT services through the social aspects of cognition, shared knowledge, and communication. A model is derived from the findings of the literatures and tested within the domain of the Malaysian agriculture public sectors using quantitative method. Results indicate that there are positive impacts of social dimensions towards business-IT alignment and thus has a significant impact towards IT service quality. This model reveals the insight on the importance of social alignment dimension factors in achieving better IT service quality in government agency setting.
\end{abstract}

Keywords: Business-IT alignment, IT Services Quality, Communication, Cognition, Shared Knowledge

\section{Introduction}

Information technology (IT) has become a broad concept centered on the IT department or delivering business value to the organizations. IT consists of a set of regulations, policies and a set of rules, which ensure the effectiveness, controlled and valuable operation of the department in an organization. IT governance can be defined as the process to ensure the effective and efficient use of IT in the organization in achieving its vision and mission. The main goal of IT governance is to transform IT as well as to align the IT strategy and business strategy for sustainability, with the aim of improving the performance of the organization [1]. Utilizing IT governance is argued to be able to mitigate the risk and deliver transparency by evaluating the processes and outcome [2]. The importance and benefit in governing IT has become accepted and recognized in the organization around the world [3]. Various studies adopting the IT governance framework have been successful in ensuring that the IT department within the organization achieves their targeted service quality. Many of these organizations are within the private sector focusing on businesses relating to IT solutions, IT helpdesks and service providers. Due to the success stories of these organizations, government agencies are also currently looking into the aspects of business-IT alignment as a starting point towards a holistic adoption of IT governance to be implemented in the ministries and agencies. These ministries and agencies may not just be technology related but also relating to finance, education, health, and agriculture. The focus of this study is specific to the agriculture sector due to the little attention given to the use of computing technologies within this domain. However, in meeting the demands of the current economic and vast technological era, the agricultural sector plays an important role in the inclusive development of a sustainable nation. Agricultural sectors' role in economic development has become significant in reducing poverty and safeguarding national food security. Within the Malaysian context, the produce from the agricultural sector has become a global demand, as this sector is rapidly increasing in many parts of Malaysia. The aim of agriculture's sectors is to double the contribution to the Gross National Income (GNI) by increasing the production of high-value products and growing the produce that is made into downstream products. Moreover, the increase of produce will transform traditional agriculture into a strategic agribusiness model covering market-centricity, economies of scales and value chain integration. In achieving the objectives of the agricultural sector as stated above, the use of computing technologies is needed to meet the demands of the agriculture businesses.

In general, the governmental organizational structure has two (2) categories of stakeholders that are involved with IT implementation. The business stakeholders, which include the board of directors, managers and executives from the Malaysian agriculture public sectors and the IT segment, consisting of IT personnel from internal IT unit and vendors providing IT services and infrastructure. IT planning and risk management is crucial, as the investment is rather large. Hence, it is required for the stakeholders to attend the planning, supervision and coordination sessions that address the strategic level of sustainable decisions. These decisions would then be implemented by the operational level in the form of organizational processes. A full support from the opera- 
tional level with clear objectives is essential in providing the sustainability and competitive advantage of the agricultural sector [4]. This is also reflected on the mutual understanding among business and IT segments, as it is crucial in realizing the business goals. IT segments have to ensure that the application and facilities are capable to cater the needs of the business stakeholders effectively and efficiently.

However, the working culture of the business segments are usually less synchronized with the technology and governance of IT. Hence, the impact of improper management of IT will lead to lack of commitment from the business segments and top management, leading to unsatisfied users of the IT applications. Furthermore, this misalignment will also cause bad reputation to the government agencies, as the agricultural sector is still significantly slow in terms of computing and IT development as compared to other neighboring countries. In order to ensure that the agricultural agency is prepared for the holistic IT governance adoption as a strategy to improve organizational performance, it is imperative that a study must first be carried out in identifying whether the business-IT alignment factors actually lead to better IT service quality.

\section{Literature Review}

The information technology (IT) and information systems (IS) revolution have increased the importance of aligning IT with the business objectives among IT executives. Business-IT alignment enables the IS to meet the business environment evolution [5], [6]. Business-IT alignment applies to information technology (IT) in harmonizing the processes with business strategies, goals and needs. Luftman [7] defines business-IT alignment as integrating IT with business strategies, goals and needs applicable for both business and IT executives. Seman \& Salim [8] also describes business-IT alignment as shared mission, objectives and planning with the business strategy and supported with IT objectives. The alignment of business and IT would be the main focus in assuring the coordination of organization plans and goals, support each other as a structured unit. Kashanchi \& Toland [9] discovered that organizations benefit from business-IT alignment through the return of IT investment, achieving competitive advantage whils taking new action to new opportunity with the right direction and flexibility [10]. Several studies by Broadbent \& Weill [11], Croteau \& Bergeron [12] and Hu \& Huang [13] also suggests that the lack of alignment between business and IT unit would affect the full potential of IT investment.

Several studies on business-IT alignment emphasized the needs to align business and IT in an organization. The studies covered definition of alignment, dimensions of alignment [9], [14] while other research focused on models or framework of integrating business with the IT unit [8], [15], [16]. Cragg, King, \& Hussin [17] have also discovered a significant proportion of small firms that achieved better organizational performance through the implementation of business-IT alignment. Studies by Chan, Sabherwal, \& Thatcher [18] identified factors relating to alignment that have the significant impact on organizational performance. In relation to the studies of identifying factors to business-IT alignment, Charoensuk, Wongsurawat, \& Khang, [19] have also suggested that the business-IT alignment actually does have a positive impact on hotels in Thailand.

Considerable amount of literatures has been published on business-IT alignment and the implementation plan. However, there is still lack of empirical studies that clarifies the business-IT implementation strategies into regular business processes and projects [20]. In addition, without the readiness of the organization's IT unit in providing better service quality, paired with business-IT alignment factors, the governance of IT may be difficult to be achieved.

\subsection{Business-IT Alignment Dimensions}

Previous researchers have highlighted the importance of aligning business with IT in the organization that might steer better governance of IT leading towards the organizational performance [8], [18]. Nevertheless, there are still few studies highlighting the critical factors that affects business-IT alignment within the Malaysian context. Studies by Kashanchi \& Toland and Reich \& Benbasat [9], [14]; argued that the strategic alignment comprises of two dimensions; which are the intellectual and social dimension. Reich \& Benbasat [21] highlights the need of both dimensions for a well-aligned business performance. Social dimension of alignment is recognized as "the state in which business and IT executives within an organizational unit understand and committed to the business and IT mission, objectives and plans" [9], [21]. The social alignment dimension also addresses the factor of relational, informal and cultural aspects [22].

This paper considers the understanding of social dimension in terms of coordination and other related aspects that have an effect on alignment. This dimension is less considered by researchers as the organizational understanding and commitment may be challenging [14], [23], [24]. The social dimension is used to understand how different players in an organization or unit under this study view IT. Shamkeh 2008 [25] indicated that social dimension of alignment in combination with intellectual dimension, will provide an effect on strategic alignment realization. Furthermore social alignment also undermines the effect of intellectual alignment on organizational inertia [26]. It has been statistically proven by Mezghani [27], that interpersonal skill do affect the alignment and provide more importance than the technical aspect. This finding is inconsistent with the previous studies that highlight the significance of technical skills to influence business-IT alignment.

A number of empirical studies have found that the importance of business-IT alignment in an organization is required in order to achieve better governance of IT leading towards organizational performance [8], [18], [19]. Nevertheless, there are still very few studies highlighting the effects of business-IT alignment towards IT service quality within the Malaysian context. Therefore, this study specifically incorporates the social dimension and examines business-IT alignment influences towards service quality in a Malaysian agriculture perspective that is currently less represented in the research literature.

\subsection{Challenges}

Information technology (IT) department's function is to give IT support and provide services to the business units that acquire data, application, and communication infrastructure. Additionally, the ideal alignment ensures IT strategy influences the business unit by managing various IT infrastructure and processes. The development of a positive collaboration between business and IT people across the organization is important to achieve high-level alignment. The business-IT alignment domain has become an important research due to the challenges of operationalizing it into practice. It is critical to build a good relationship with business and IT people in order to accomplish a higher level of alignment. Previous literature have highlighted the issues of misalignment between business and IT in various context [14], [16], [28].

Feeny, Edwards and Simponson [29] discovered the main factors that affect business-IT alignment include interaction, internal, and external organizations and the social connection with CEO and CIO's. In order to accomplish the alignment, several issues related to knowledge, locus of control, and organizational change are the main challenges [30]. Issues on knowledge is identified as the main obstacle for organizations where the IT unit is not included in corporate strategies, causing the senior managements to have limited knowledge in IT. The issue on locus of control is more related to the decision making by the senior management, as it is argued that senior management always make decision based 
on their authority without considering the strategy that may affect the IT unit [8], [31]. Organizational change issue refers to the capability of the organization in implementing IT planning according to the globalization of business environment [8].

A study by Alaceva and Rusu [23] found that low communication, poor understanding, lack of cooperation and mutual support actually affects good business and IT alignment. Lack of mutual understanding between business and IT units is also one of the reasons for misalignment [32], [33]. Despite the lack of understanding between the business and IT unit and vice versa, another challenge discovered are the lag of response time due to the strict protocol between business-IT strategies and miscommunication in understanding the business or IT operations [34]. Therefore, the cooperation between business and IT people across the organization is crucial to reach a high level of alignment.

\subsection{Social Dimension Factors of Business-IT Align- ment}

Social factors of alignment such as communication, shared domain knowledge and cognitive linkages are found to be the key areas that are unified in practice [14], [21], [35], [36]. The first element of communication refers to the interaction and degree of communication among the business and IT personnel, which influences understanding and alignment. Interaction exists through meetings and conversations either formally or informally. Clear communication is crucial for alignment to be successful [16]. Many researchers highlighted that a bidirectional communication and relationship between business and IT unit is necessary for applicability of IT governance [7], [14], [37]. Kashanchi \& Toland [9] indicated that the determining factors of good communication are the flow of informal communication between internal, external and all level of organization, followed by the frequency of communication that improves the understanding. As a result, information can be shared as communications throughout the organization in a more effective manner [38]. This argument is also supported by Charoensuk, S., Wongsurawat, W., \& Khang [19] where communication and knowledge sharing in an effective way, will result to the organization being on track to achieve the objectives and goals.

Knowledge is considered as organizational expertise and act as the most important source for competitive advantage [35], [39]. Knowledge sharing is important especially in the process of ensuring the right knowledge and resources are available for the right people at the right time. Appropriate planning of the business process will derive the shared domain knowledge and influence the alignment between business and IT [40]. Reich \& Benbasat [14] defined shared domain knowledge as an intersection of business and IT personnel by having the ability to understand and participate with key processes and at the same time value other contributions and challenges. This perspective is also supported by Chan, Y. E., Sabherwal, R., \& Thatcher, J. B [18] indicating that shared domain knowledge is one of the factors that have positive impact on alignment for organizational performance.

In an organizational environment, aligning business with IT strategy would be a challenge, as people need to understand, trust and rely on each other. This challenge needs an established working linkage between business and IT as IT has become an important part in enabling the business decision and strategies [41], [42]. Cognitive linkage is the third factor focusing on the elements of trust, understanding, commitment, and respect between business and IT unit [36]. Shared understanding as suggested by Reich \& Benbasat [14] and Tan \& Gallupe [24] can be considered as the main factor in defining the social dimension of alignment. Tan \& Gallupe [24] defined shared cognition as cognition that has both commonality and individuality.

Commonality involves cognitive structures that are held in common among people, whereas individuality takes the form of personal cognitions that are contributed to the organizational group. There have been relatively few studies suggesting that once trusts are established, organization would learn that joint ventures will lead to results beyond the firm to be achieved [43]. Hence, it can be argued that trust is crucial for the exchange of relationships and considered as the main feature of strategic partnership.

Table 1 illustrates the findings from previous literature indicating similar factors using various terminologies and related to the social dimension of alignment. These factors are characterised based on the social dimension indicated by Reich and Benbasat [14], [23].

Table 1: Social dimension factors of business-IT alignment

\begin{tabular}{|c|c|c|}
\hline Author & $\begin{array}{l}\text { Factor of } \\
\text { Alignment }\end{array}$ & Dimension \\
\hline \multirow{3}{*}{$\begin{array}{l}\text { Kashanchi } \\
\text { and To- } \\
\text { land [35] }\end{array}$} & $\begin{array}{l}\text { 1. Unclear strategy be- } \\
\text { tween and IT staff }\end{array}$ & Connection \\
\hline & $\begin{array}{l}\text { 2. Long -term relationship } \\
\text { between business and IT }\end{array}$ & \\
\hline & $\begin{array}{l}\text { 3. Communication be- } \\
\text { tween business and IT at } \\
\text { all levels }\end{array}$ & Communication \\
\hline $\begin{array}{c}\text { Prestopn } \\
\text { and Kara- } \\
\text { hanna [44] }\end{array}$ & 1. Shared understanding & Shared domain knowledge \\
\hline \multirow{2}{*}{$\begin{array}{c}\text { Johson and } \\
\text { Lederer } \\
{[45]}\end{array}$} & $\begin{array}{l}\text { 1. Relationship between } \\
\text { business and IT execu- } \\
\text { tives }\end{array}$ & Connection \\
\hline & 2. $\quad$ Alignment direction & \\
\hline \multirow{3}{*}{$\begin{array}{l}\text { Mekzhgani } \\
\& \\
\text { Mezghani } \\
{[27]} \\
\end{array}$} & 1. Interpersonal skill & \\
\hline & 2. $\quad$ Conceptual skill & \\
\hline & 3. Communication & Communication \\
\hline Ma [46] & $\begin{array}{l}\text { 1. Shared domain } \\
\text { knowledge }\end{array}$ & Shared domain knowledge \\
\hline \multirow[t]{2}{*}{$\begin{array}{c}\text { Korhonen } \\
\text { \& kai- } \\
\text { dalova } \\
\text { [32] }\end{array}$} & $\begin{array}{l}\text { 1. Shared domain } \\
\text { knowledge between } \\
\text { business and IT execu- } \\
\text { tives }\end{array}$ & Shared domain knowledge \\
\hline & 2. $\quad$ Enterprise Model (EM) & \\
\hline \multirow{4}{*}{$\begin{array}{l}\text { Alaceva \& } \\
\text { Rusu [23] }\end{array}$} & $\begin{array}{l}\text { 1. Shared domain } \\
\text { knowledge }\end{array}$ & Shared domain knowledge \\
\hline & $\begin{array}{ll}\text { 2. IT Implementation } \\
\text { success }\end{array}$ & \\
\hline & $\begin{array}{l}\text { 3. Communication be- } \\
\text { tween business \& IT ex- } \\
\text { ecutives }\end{array}$ & Communication \\
\hline & $\begin{array}{l}\text { 4. Connections business \& } \\
\text { IT planning }\end{array}$ & Connection \\
\hline
\end{tabular}

\section{Conceptual Model}

Based on the studies highlighted in the previous section, this study suggests three (3) social dimensions of alignment consisting of communication, cognition, and shared knowledge as the factors influencing the alignment of business and IT. The conceptual model in figure 1 below is based on the findings of previous literature. In order to achieve high level of satisfaction on service quality, alignment of business and IT unit in relation to the three (3) social dimensions is important to be discussed.

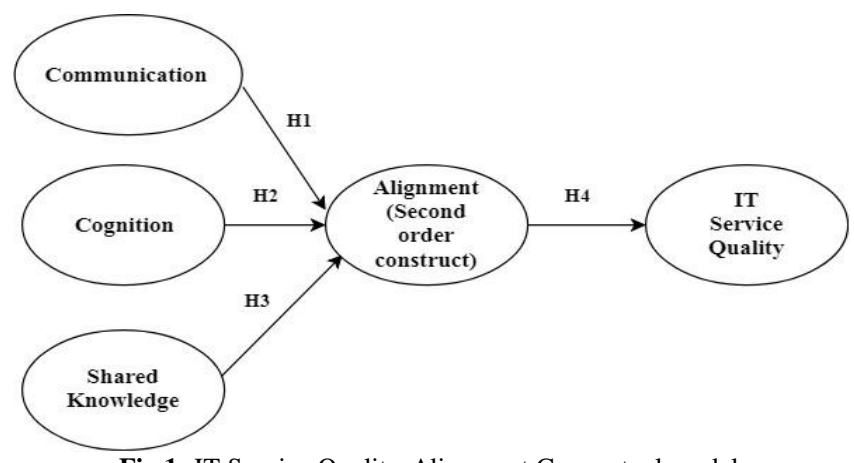

Fig 1: IT Service Quality-Alignment Conceptual model. 
In an operational environment of agriculture, the business unit includes board of directors, managers and executives. The second segment would be IT stakeholders involving internal IT unit and external IT service providers. Considering the communication dimension of alignment, effective, and efficient two-way communication between the business and IT unit is important for better and clearer understanding of information. As an example, requirements from the business unit should be well informed as the IT unit may not be familiar with the business environment and processes. Channels for interaction between these two parties must be available for accurate and faster dissemination of knowledge between business and IT unit in a more secure manner. This would provide a faster solution-oriented reaction by the IT unit to facilitate the needs of the business units.

Cognitive is the second business-IT alignment dimension to influence alignment and facilitate service quality. Cognitive addresses the individual or organization factors such as trust, commitment, understanding and also respect between the business and IT unit This dimension is crucial in business-IT alignment as it provides the cooperation and reliance on each other in order to achieve the organization objectives. Furthermore, with the cooperation between the business and IT unit, knowledge sharing and transference would be easy, as both parties understand their roles.

The third dimension is shared knowledge, whereby without knowledge between both parties, it is impossible to execute the strategies smoothly according to plan. Internal IT unit's knowledge on business processes and environment is one of the focus areas to be considered and vice versa. Furthermore, the knowledge on IT process and the environment would help the business unit to understand the situation and needs to be fulfilled by the IT unit. Thus, the IT unit's knowledge on business process would improve the IT service quality to the requirements of the business unit.

As the three (3) social dimensions of alignment are related, thus it represents the alignment as a second-order construct. Based on the arguments above, the hypotheses formed are as below:

$\mathbf{H}$ Communication in the organizations positively affects the 1: business-IT alignment.

H. Cognition have positively affects the business-IT alignment.

2: $\quad$ Shared knowledge in the organizations positively affects the 3: business-IT alignment.

$\mathbf{H}$ Business-IT alignment positively affects the quality of IT 4: $\quad$ service quality.

\section{Methodology}

This section depicts the data collection that is used for this study. In order to empirically validate the conceptual model, a survey was conducted on the staff that comes from various business units of the departments and agencies under the Ministry of Agriculture and Agro-based Industry (MOA). The duration of the survey is one month and are designed in both English and Malay language to meet the language requirements of the local participants. Google Form application was used aside from surveys sent via email and some in a form of survey booklet delivered by hand. From more than 200 emails and questionnaire booklet sent to the respondent, 178 responses were received, representing a response rate of $89 \%$.

The survey incorporated questions with mixed-type responses and the respondents have to complete two (2) sections. Section 1- a general socio-demographic profile questions and general information of working experience, grade, serving organization of the respondents. Section 2 consists of business-IT alignment factors. Results were then analyzed statistically using statistical tools for descriptive analysis. In providing confirmation on the hypotheses, data was also analyzed using a structured equation modeling (SEM) tool for confirmatory factor analysis. The SEM-PLS was used to derive the final model.

\section{Results}

The aim of the demographic profiles is to identify the information of respondent's background including gender, age group, current organizations, work position and working experience. Female constitutes $54 \%$ of the respondents while male respondents is $46 \%$. The majority of the respondent are aged between 31-40 years which is depicted in Figure 2.73\% of the respondents are working in agencies with more than 500 people and $41 \%$ of the respondents have only 1-10 years of working experience, which indicate that they come from a younger age group of employees.

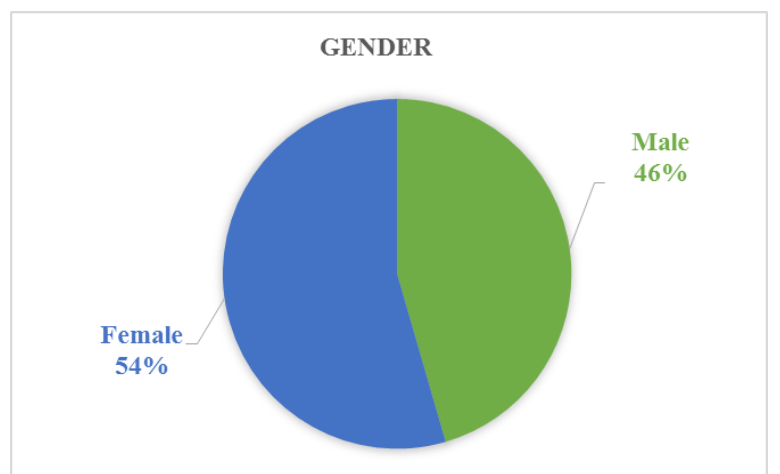

Fig 1: The percentage of respondents according to gender

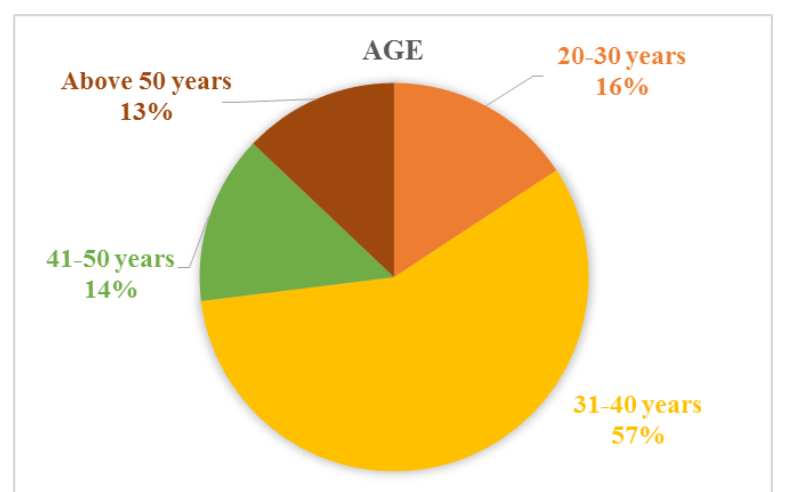

Fig 2: The percentage age of respondents

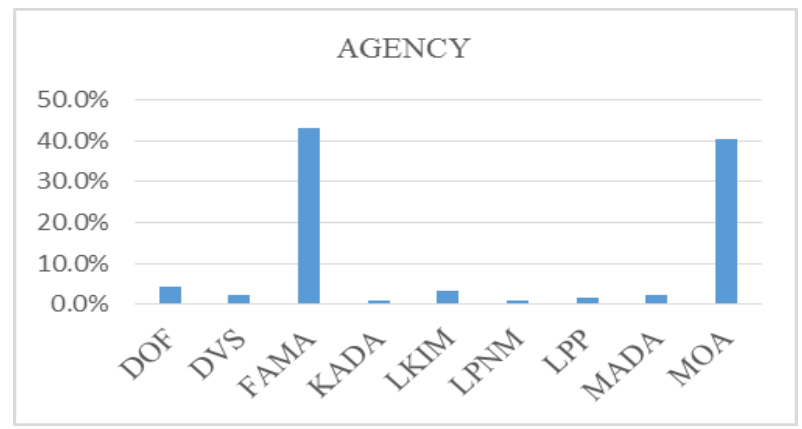

Fig 3: The percentage of the agency

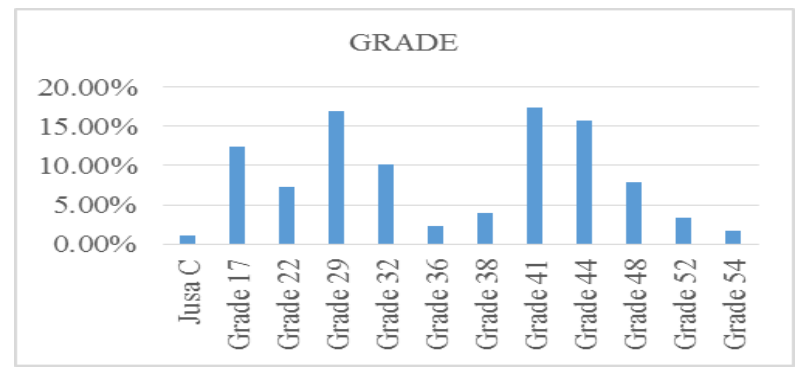

Fig 4: The percentage of the respondent's grade

Figure 3 highlighted only nine (9) agencies took part in the survey, where most of the respondents are from Federal Agriculture Mar- 
keting Authority (FAMA) $43.3 \%$ and followed by the Ministry of Agriculture and Agro-based Industry (MOA) with 40.4\%. In addition, $41 \%$ of the respondents are working in large agencies with more than 500 people. This indicates the IT unit in the agencies above has to respond to a high number of users from various business units. Furthermore, figure 4 indicates $17.42 \%$ of the participants are government officers with middle management grade and $16.58 \%$ participant are assistant officers. This finding shows that they have experiences working with IT personnel.

The SmartPLS v3 software is used in this study to analyze the reliability and validity. The test of the internal consistency, composite reliability and convergent validity was carried out to analyze the model. The factor loading and T-values of the construct are calculated and displayed in Table 2. It is advised that the factor loading must be above 0.7 and not below than 0.5 [47], thus, the item ACM 1, ACM 2, ACM 7 and ACM 8 have to be eliminated as the values are below the requirement.

Table 2: Measurement of the model parameters

\begin{tabular}{|c|c|c|c|}
\hline Construct & Item & Loading & T Value \\
\hline \multirow{4}{*}{$\begin{array}{c}\text { Alignment } \\
\text { (Communication) }\end{array}$} & ACM3 & 0.720 & 14.749 \\
\hline & ACM4 & 0.787 & 22.35 \\
\hline & ACM5 & 0.712 & 12.581 \\
\hline & ACM6 & 0.702 & 13.368 \\
\hline \multirow{5}{*}{$\begin{array}{l}\text { Alignment } \\
\text { (Cognition) }\end{array}$} & $\mathrm{AC} 1$ & 0.800 & 22.97 \\
\hline & $\mathrm{AC} 2$ & 0.794 & 19.86 \\
\hline & $\mathrm{AC} 3$ & 0.793 & 18.945 \\
\hline & $\mathrm{AC} 4$ & 0.805 & 20.795 \\
\hline & AC5 & 0.748 & 11.516 \\
\hline \multirow{4}{*}{$\begin{array}{c}\text { Alignment } \\
\text { (Shared Knowledge) }\end{array}$} & ASK1 & 0.768 & 18.423 \\
\hline & ASK2 & 0.748 & 18.847 \\
\hline & ASK3 & 0.707 & 12.101 \\
\hline & ASK4 & 0.736 & $14 . .478$ \\
\hline \multirow{7}{*}{$\begin{array}{l}\text { IT Service } \\
\text { Quality }\end{array}$} & SQ1 & 0.894 & 37.127 \\
\hline & SQ2 & 0.883 & 33.526 \\
\hline & SQ3 & 0.884 & 27.934 \\
\hline & SQ4 & 0.830 & 22.812 \\
\hline & SQ5 & 0.882 & 46.976 \\
\hline & SQ6 & 0.770 & 9.444 \\
\hline & SQ7 & 0.894 & 40.951 \\
\hline
\end{tabular}

Table 3 displays the Cronbach's alpha of the model, where higher than 0.7 indicates that the item form a scale that has reasonable (very good) internal consistency reliability. The composite reliability in Table 4 demonstrates all the variables are above 0.7 and indicates a strong consistency.

The convergent validity can be tested if the AVE of the each latent (variable) surpassed 0.5 [48] and fulfills the requirement.

Table 3: Internal Consistency Analysis

\begin{tabular}{|l|r|r|r|r|}
\hline \multicolumn{1}{|c|}{ Construct } & $\begin{array}{c}\text { Cronbach's } \\
\text { Alpha }\end{array}$ & $\begin{array}{c}\text { Composite } \\
\text { Reliability }\end{array}$ & $\begin{array}{c}\text { Average } \\
\text { Variance } \\
\text { Extracted } \\
\text { (AVE) }\end{array}$ & $\begin{array}{c}\text { R } \\
\text { square }\end{array}$ \\
\hline Cognition & 0.904 & 0.929 & 0.722 & \\
\hline Communication & 0.850 & 0.890 & 0.577 & \\
\hline $\begin{array}{l}\text { Shared Knowl- } \\
\text { edge }\end{array}$ & 0.838 & 0.892 & 0.675 & \\
\hline $\begin{array}{l}\text { IT Service Qual- } \\
\text { ity }\end{array}$ & 0.943 & 0.953 & 0.746 & 0.419 \\
\hline
\end{tabular}

Table 4: Result of testing discriminant validity

\begin{tabular}{|l|r|r|l|l|}
\hline & $\begin{array}{l}\text { Cogni- } \\
\text { tion }\end{array}$ & $\begin{array}{l}\text { Communica- } \\
\text { tion }\end{array}$ & $\begin{array}{l}\text { ST } \\
\text { Ser- } \\
\text { vice } \\
\text { Qual- } \\
\text { ity }\end{array}$ & $\begin{array}{l}\text { Shared } \\
\text { Knowl- } \\
\text { edge }\end{array}$ \\
\hline Cognition & 0.850 & & & \\
\hline Communication & 0.713 & 0.831 & & \\
\hline $\begin{array}{l}\text { IT Service Qual- } \\
\text { ity }\end{array}$ & 0.636 & 0.503 & 0.863 & \\
\hline $\begin{array}{l}\text { Shared Knowl- } \\
\text { edge }\end{array}$ & 0.752 & 0.72 & 0.599 & 0.822 \\
\hline
\end{tabular}

Table 4 illustrates the result of correlation testing on the latent variables. Findings indicates that discriminant validity is well established for this study. It is also interesting to note that the square root of the AVE have a larger number than other latent variables. This can be concluded that the result have a well establish discriminant validity.

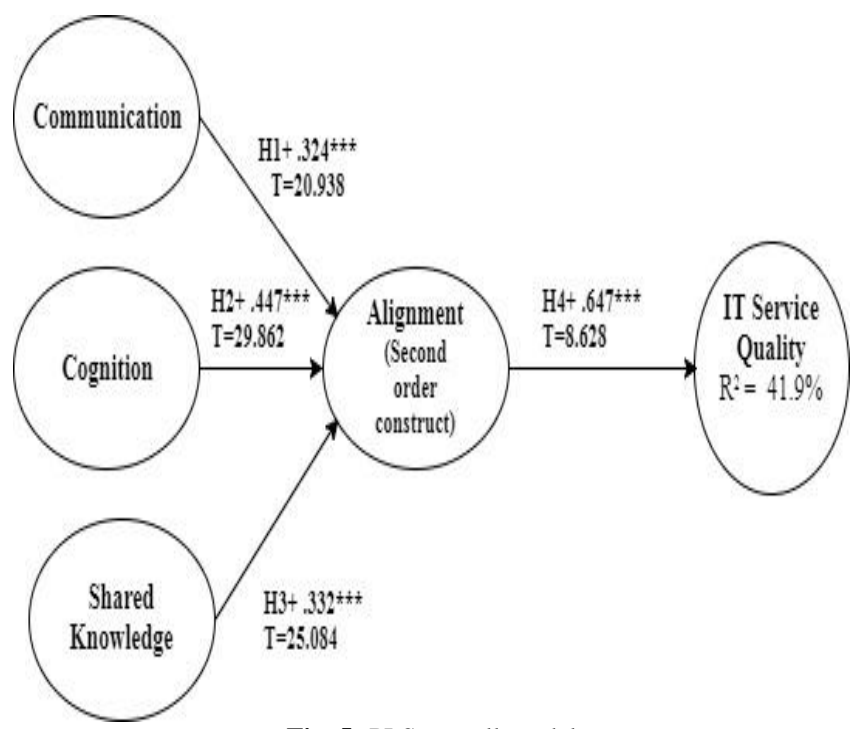

Fig. 5: PLS overall model

The $R^{2}$ for IT service quality value present in this study obtained as $41.9 \%$ and considered as medium predictive accuracy, and fulfill the requirement of $R^{2}$ value. The overall model indicates the result of the assessment. It can be concluded the hypotheses H1, $\mathrm{H} 2, \mathrm{H} 3$ and $\mathrm{H} 4$ are all accepted. In addition the communication, cognition and shared knowledge indeed have strong affect to derive the alignment between business and IT. Moreover, result also shows a strong positive effect towards IT service quality (H4). Hence the alignment have a positive impact on the quality of service provided by IT unit.

\section{Conclusion}

Aligning business and IT strategic concept has been an ongoing debate for more than 30 years. Researchers have developed numerous business-IT alignment models and made enhancements to the alignment aspects that benefit both the public and private organizations. IT governance has been argued as one of the effective mechanisms in ensuring the level of service provided by the IT department is of acceptable level. In ensuring that the overall aim to achieve good IT governance, the level of service provided by the IT department has to be of a satisfactory level. Thus, in achieving the level of satisfaction form all stakeholders, business and IT has to be coordinated and communicated in the same language in achieving the desired alignment.

Business-IT alignment consists of shared mission, objectives and goals within the business strategy, in ensuring all targeted objectives are met. It is expected that all departments understand the goals to be achieved with excellent support by the IT department. Unfortunately, this has not always been a success story. Previous studies have indicated that misalignment between business and IT have caused dissatisfaction to the business users of IT. With the lack of support and understanding from the IT department and lack of utilization of alignment factors, efficiency in providing excellent services is difficult to achieve.

The relationship between business-IT is relevant in ensuring better service quality is provided by the respective stakeholders. Literature analysis indicates that social factors can be significantly considered as a dimension for alignment [36]. Hence, there is a need to identify critical factors that lead to better alignment and this leads to better service quality. There are two key contributions of 
this study. The first is to identify the value of business-IT alignment at operational level. The dimension consists of communication, cognition and shared knowledge influencing the alignment at the operational level to obtain high quality service. Secondly, to validate the conceptual model in analyzing relationship between business-IT alignment within the Malaysian public agriculture sector. Furthermore, these relationships and best practices can assist the organization in attaining the alignment. As a result, organization that achieve good alignment would be able to gain benefits from the IT systems and improve performance. Moreover, the organization would also learn to better managing people in both business and IT in meeting future challenges.

\section{Acknowledgement}

I would like to thank my postgraduate supervisor and all anonymous researchers who were involved for their valuable comments on this manuscript.

\section{References}

[1] S. De Haes and W. Van Grembergen, "IT Governance Structures, Processes and Relational Mechanisms: Achieving IT/Business Alignment in a Major Belgian Financial Group," Proc. 38th Annu. Hawaii Int. Conf. Syst. Sci., vol. 00, no. C, p. 237b-237b, 2005

[2] H. Heier, H. P. Borgman, and B. Bahli, "Cloudrise: Opportunities and challenges for IT governance at the dawn of cloud computing," in Proceedings of the Annual Hawaii International Conference on System Sciences, 2012, pp. 4982-4991.

[3] ITGI, "Global Status Report on the Governance of Enterprise It ( GEIt )—2011," Gov. An Int. J. Policy Adm., p. 70, 2011.

[4] H. Junker and T. Farzad, "Towards Sustainability Information Systems," Procedia Comput. Sci., vol. 64, pp. 1130-1139, 2015.

[5] J. Orozco, A. Tarhini, R. (Moh'd T. Masa'deh, and T. Tarhini, “A Framework of IS/Business Alignment Management Practices to Improve the Design of IT Governance Architectures," Int. J. Bus. Manag., vol. 10, no. 4, pp. 1-12, 2015.

[6] A. Tarhini, T. Teo, and T. Tarhini, "A cross-cultural validity of the E-learning Acceptance Measure (ElAM) in Lebanon and England: A confirmatory factor analysis," Educ. Inf. Technol., vol. 21, no. 5, pp. 1269-1282, 2016.

[7] J. N. Luftman, "Assessing Business-IT Alignment Maturity," Strateg. Inf. Technol., vol. 4, no. December, pp. 1-51, 2000.

[8] E. A. A. Seman and J. Salim, "A Model for Business-IT Alignment in Malaysian Public Universities," Procedia Technol., vol. 11, no. Iceei, pp. 1135-1141, 2013.

[9] R. Kashanchi and J. Toland, "Investigating the Social Dimension of Alignment: Focusing on Communication and Knowledge Sharing," ACIS 2008 Proc., no. 2, pp. 462-472, 2008

[10] D. Avison, J. Jones, P. Powell, and D. Wilson, "Using and validating the strategic alignment model," J. Strateg. Inf. Syst., vol. 13, no. 3, pp. 223-246, 2004

[11] M. Broadbent and P. Weill, "Improving business and information strategy alignment: Learning from the banking industry," IBM Syst. J., vol. 32, no. 1, pp. 162-179, 1993.

[12] A. M. Croteau and F. Bergeron, "An information technology trilogy: Business strategy, technological deployment and organizational performance," J. Strateg. Inf. Syst., vol. 10, no. 2, pp 77-99, 2001

[13] Q. Hu and C. D. Huang, "Using the Balanced Scorecard to Achieve Sustained IT-Business Alignment: A Case Study," Commun. AIS vol. 17, no. 8, pp. 2-46, 2006.

[14] B. H. Reich and I. Benbasat, "Factors That Influence the Social Dimension of Alignment between Business and Information Technology Objectives," MIS Q., vol. 24, no. 1, p. 81, 2000.

[15] J. C. Henderson and N. Venkatraman, "Strategic Alignment: Leveraging Informatopn Technology for Transforming Organizations.," IBM Syst. J. Vol 32, No.1, vol. 22, no. 11, p. 44 1993.

[16] J. Luftman, R. Papp, and T. Brier, "Enablers and inhibitors of business-IT alignment," Commun. AIS, vol. 1, no. 3es, pp. 1-33, 1999.

[17] P. Cragg, M. King, and H. Hussin, "IT alignment and firm performance in small manufacturing firms," J. Strateg. Inf. Syst., vol. 11 , no. 2 , pp. 109-132, 2002

[18] Y. E. Chan, R. Sabherwal, and J. B. Thatcher, "Antecedents and outcomes of strategic IS alignment: An empirical investigation," IEEE Trans. Eng. Manag., vol. 53, no. 1, pp. 27-47, 2006.

[19] S. Charoensuk, W. Wongsurawat, and D. B. Khang, "Business-IT Alignment: A practical research approach," J. High Technol. Manag. Res., vol. 25, no. 2, pp. 132-147, 2014.

[20] A. Ghildyal and E. Chang, "IT Governance, IT / Business Alignment and Organization Performance for Public Sectors," vol. 5, no. 6, 2017

[21] B. H. Reich and I. Benbasat, "Measuring the Linkage between Business and Information Technology Objectives," MIS Q., vol. 20 , no. 1 , p. $55,1996$.

[22] F. Schlosser, H. T. Wagner, and T. Coltman, "Reconsidering the dimensions of business-IT alignment," Proc. Annu. Hawaii Int Conf. Syst. Sci., pp. 5053-5061, 2012.

[23] C. Alaceva and L. Rusu, "Barriers in achieving business/IT alignment in a large Swedish company: What we have learned?," Comput. Human Behav., vol. 51, pp. 715-728, 2015.

[24] F. B. Tan and R. B. Gallupe, "Aligning business and information systems thinking: A cognitive approach," IEEE Trans. Eng. Manag. vol. 53, no. 2, pp. 223-237, 2006

[25] F. R. Shamekh, "Business-IT Strategic Alignment Concept in Theory and Practice," 2008

[26] H. Liang, N. Wang, Y. Xue, and S. Ge, "Unraveling the Alignment Paradox: How Does Business - IT Alignment Shape Organizational Agility? Unraveling the Alignment Paradox : How Does Business - IT Alignment Shape Organizational Agility?,' no. May 2018, pp. 0-17, 2017.

[27] K. Mezghani and L. Mezghani, "Effects of Business Managers Skills on Enterprise Resources Planning Strategic Alignment," vol. 3 , no. 1, pp. 15-20, 2014.

[28] P. Mikalef, "Business / IT Maturity and Alignment Issues," 2010.

[29] D. F. Feeny, B. R. Edwards, K. M. Simpson, C. E. O. Cio, and B. R. Edwards, "Understading the CEO/CIO Relationship," vol. 16, no. 4, pp. 435-448, 1992.

[30] Y. E. Chan and B. H. Reich, "IT alignment: What have we learned?," J. Inf. Technol., vol. 22, no. 4, pp. 297-315, 2007.

[31] B. Campbell, R. Kay, and D. Avison, "Strategic Alignment: a Practitioner' S Perspective," Eur. Mediterannean Conf. Inf. Syst., no. July, pp. 25-27, 2004.

[32] J. J. Korhonen and J. Kaidalova, "Enterprise Modeling Facilitating Business and IT Alignment Along the Social Dimension: Stakeholder Intentions for Model-Based Communication and Coordination," Proc. - 17th IEEE Conf. Bus. Informatics, CBI 2015 vol. 2, pp. 1-8, 2015.

[33] S. N. Singh and C. Woo, "Investigating business-IT alignment through multi-disciplinary goal concepts," Requir. Eng., vol. 14, no 3, pp. 177-207, 2009

[34] P. O. John and R. Tarabay, "Time is Money! Time lag management in Business-IT Strategy: Emprical Validation of Theories," Jönköping International Business School, Jönköping University, JIBS, Business Informatics, 2011.

[35] R. Kashanchi and J. Toland, "Investigating the Social Dimension of Alignment : Focusing on Communication and Knowledge Sharing," 2008.

[36] F. Schlosser, H. T. Wagner, D. Beimborn, and T. Weitzel, "The role of internal business/IT alignment and IT governance for service quality in IT outsourcing arrangements," Proc. Аnnu. Hawaii Int. Conf. Syst. Sci., pp. 1-10, 2010.

[37] S. De Haes and W. Van Grembergen, "IT Governance Structures, Processes and Relational Mechanisms: Achieving IT/Business Alignment in a Major Belgian Financial Group," Proc. 38th Annu. Hawaii Int. Conf. Syst. Sci., p. 237b-237b, 2005.

[38] S. H. Chung, R. K. R. Jr., and B. R. Lewis, "The Impact of Information Technology Infrastructure Flexibility on Strategic Alignment and Application Implementations," J. Vis., vol. 11, 2003

[39] I. Benbstat and G. Bassellier, "Business Competence of Information Development and Influence on Technology Professionals : Conceptual," MIS Q., vol. 28, no. 4, pp. 673-694, 2004.

[40] A. Ullah and R. Lai, "A Systematic Review of Business and Information Technology Alignment," ACM Trans. Manag. Inf. Syst., vol. 4, no. 1, pp. 1-30, 2013.

[41] J. Coughlan, M. Lycett, and R. D. Macredie, "Understanding the business-IT relationship," Int. J. Inf. Manage., vol. 25, no. 4, pp. 303-319, 2005

[42] C. M. Hinton and G. R. Kaye, "The hidden investments in 
information technology: The role of organisational context and system dependency," Int. J. Inf. Manage., vol. 16, no. 6, pp. 413427, 1996.

[43] C. Young-Ybarra and M. Wiersema, "Strategic Flexibility in Information Technology Alliances: The Influence of Transaction Cost Economics and Social Exchange Theory," Organ. Sci., vol. 10, no. 4, pp. 439-459, 1999.

[44] D. S. Preston and E. Karahanna, "Antecedents of IS strategic alignment: A nomological network," Inf. Syst. Res., vol. 20, no. 2, pp. 159-179, 2009.

[45] A. M. Johnson and A. L. Lederer, "CEO/CIO mutual understanding, strategic alignment, and the contribution of IS to the organization," Inf. Manag., vol. 47, no. 3, pp. 138-149, 2010.

[46] S. Ma, "Investigation of the strategic alignment in public sector organisations using knowledge based strategy," vol. 18, no. 11, pp. 631-636, 2014.

[47] J. Hulland, "Use Of Partial Least Squares (PLS) In Strategic Management Research: A Review Of Four Recent Studies," vol. 204, no. November 1996, pp. 195-204, 1999.

[48] Fornell and D. F. Larcker, "Evaluating structural equation models with unobservable variables and measurement error," J. Mark. Res., vol. 18 , no. 1 , pp. $39-50,1981$. 